\title{
Differentiation of Forest Vegetation after Clear-Cuttings in the Ural Montains
}

\author{
Natalya Ivanova ${ }^{1}$ \\ ${ }^{1}$ Botanical Garden of Ural Branch RAS, Yekaterinburg, Russia \\ Correspondence: $8^{\text {th }}$ March Str., 202, Botanical Garden of Ural Branch RAS, Yekaterinburg, 620144, Russia. Tel: \\ 7-902-87-123-27. E-mail: i.n.s@bk.ru
}

Received: September 11, 2014 Accepted: September 25, 2014 Online Published: October 23, 2014

doi:10.5539/mas.v8n6p195 URL: http://dx.doi.org/10.5539/mas.v8n6p195

\begin{abstract}
The purpose of this paper is to study dynamics patterns of the Ural (Russia) forest ecosystems to allow their biodiversity conservation in the context of anthropogenic impact. One of our objectives was to test the hypothesis that external factors cause splitting-up of natural forests and their replacement by a range of successional series. Our research was conducted in the Southern Ural Mountains. We studied differentiation of the forest vegetation after clear-cuttings in the most typical environments: on smooth slopes 1-2 degrees steep with deep soils, at 400-500 $\mathrm{m}$ above the sea level. Tree stand, understory, and grass layer were studied within a number of sampling plots $(0.5 \mathrm{ha})$. To measure biomass of grass and shrub layer laid $10-15$ subplots $(0.5 \mathrm{x} 0.5 \mathrm{~m})$ within each sampling area. The obtained data was used in Correspondence Analysis (CA). For numerical analysis we used R package vegan. We found that clear-cuttings in the Southern Ural Mountains cause profound transformation of the forest vegetation structure and in all the layers. Patterns of regeneration-age dynamics differ both in tree stand and herbaceous layer: within a single natural forest, a whole range of alternative successional series are formed spruce, fir, birch, and aspen forests (short-term, long-term, and stable-term secondary), each having specific productivity of herbaceous layer. All the studied after-cutting forests (after-cutting (secondary) 50-70-year-old spruce and fir forests, short-term secondary birch forests (age of 5-100), long-term secondary birch forests (age of 20-100), and 8-110-year-old stable-term secondary aspen forests) differ from natural dark coniferous forests in the structure of herbaceous biomass and dynamic patterns. The differences between natural and after-cutting forests remain for over 100 years.
\end{abstract}

Keywords: forest ecosystem, dark coniferous forest, clear-cuttings, reforestation, secondary forest

\section{Introduction}

\subsection{Introduce the Problem}

The enormous scale of commercial forests utilization globally has led to major changes in their structure. Natural forest areas are dramatically shrinking being replaced with secondary forests, depletion of the species composition and gene pool is underway followed by downfall in stability and environmental functions of the ecosystems (Forster, 1988; Asner et al, 2009; van Breugel et al, 2014; Ivanova, 2014; Lindenmayer et al, 2014). High rates of destruction of natural ecosystems and loss of biodiversity threaten the stability of the biosphere and human livelihoods. More than $20 \%$ of the world's forest ecosystems are in Russia. They are of paramount importance to maintain the stability of the biosphere (Global Biodiversity Outlook, 2006).

In this regard, it seems of immediate importance to study region-specific and landscape-specific transformations of ecosystems and model probable consequences of their utilization. In the Ural Mountains region, industrial logging has been carried out for approximately 300 years. Intensive cutting and other forms of industrial disturbance of the mountain dark conifers of the Southern Ural (the ecotone forests on the border between Europe and Asia) have brought about a highly mosaic structure of vegetation represented by various types of forests at different stages of regeneration and age succession (Shirokikh et al, 2013). The study of forest ecosystem development and reforestation patterns in the natural dark coniferous forests (at the southern boundary of their geography) is a major concern for modern forestry, a science of vegetation and forest typology. The knowledge of forest vegetation state and dynamics is crucial for planning adequate environment protection and forestry activities to preserve the biodiversity of the unique mountain forests. 


\subsection{Purpose and Objectives}

The purpose of this paper is to study dynamic patterns in the Ural forest ecosystems in order to ensure conservation of their biodiversity in the context of anthropogenic impact.

One of our objectives was to test the hypothesis of splitting-up of natural forest types under the action of external factors and replacement of a single natural forest type by a number of different vegetation communities.

The following issues were under research:

specifics of structural and dynamic destabilization of forest ecosystems depending on the external factor type and intensity;

The range and patterns of vegetation community structure diversification;

Conjugacy of dynamics of forest vegetation layers and species.

\section{Method}

\subsection{Study Area}

We conducted our research on the territory of Katav-Ivanovsk forestry, the Chelyabinsk region (Southern Urals, Russia) between $54^{\circ} 33^{\prime}-54^{\circ} 40^{\prime} \mathrm{N} ; 57^{\circ} 48^{\prime}-57^{\circ} 55^{\prime} \mathrm{L}$. Geobotanic studies in the state-owned forests are not prohibited by the laws of the Russian Federation. No endangered plants or animals were collected.

These forests are typical for the Yuryuzan-Verkhneaysk province of the mountain taiga and mixed forests of the Ural forest region (Kolesnikov, 1969). Local climate is cold-temperate and quite humid. Average annual temperature is +2.1 , average temperature in January is around -12.5. Average temperature of May, June, and July is $+14.4^{\circ} \mathrm{C}$. Average duration of the frostless season is 120 days. Annual precipitation amounts to $580-680 \mathrm{~mm}$ on average.

\subsection{Methodological Approaches}

The basis of our work is methodological approaches geo-genetic (geodynamical) typology (Ivanova, Zolotova, 2014). Geo-genetic classification means a classification based on the forest origin and evolution patterns which takes account of all the development stages of forest ecosystem and can be used to predict their future changes. Forestry in Russia is conducted on the basis of forest typology too. For forest types been developed system of forest management.

\subsection{Research Objects}

We studied the divergence of forest vegetation on smooth slopes 1-2 degrees steep with thick (over $50 \mathrm{~cm}$ ) brown mountain forest soils at 400-500 m above the sea level. These are the most common forest vegetation conditions (observed in $74 \%$ of the total area (Andreev, 1998)). Concave and convex slopes were excluded from the analysis. Brown mountain forest soils have a profile of a brown color which is getting lighter towards the deep subsoil. Such depth ensures steady humifying of the soil. All soils are well drained due to their slope position and much detritus. Dark coniferous forests are natural for this environment. Their natural look is very homogeneous. Tree layer of these forests is represented by spruce (Picea obovata Ledeb.) and fir (Abies sibirica Ledeb.) combined in various ratios, with occasional birch (Betula pubescens Ehrh.). Secondary forests are represented by birch and aspen. These forests are very productive. Forest management is in them intensively for over 250 years. Almost all forests have suffered from clearcuts. This paper concentrates on the distinctive features of their after-cutting dynamics.

\subsection{Sampling Procedures}

The 0.5 ha sampling plots were laid according to the common methods (Forest Communities Study Methods, 2002). The plots were studied with regard to their tree stand, understory, and grass layer. Tree layer characteristics had been provided by G.V. Andreev. We counted all the trees on the sampling plot, measured their diameter, height, identified age (by the annual rings). Key taxation data are presented in Tables 1, 2. For shrubs defined projective cover. Biomass of herbaceous layer was adopted as the integral characteristic of its role in the forest ecosystem. Biomass is the product of all the environmental factors affecting the plant life cycle. To measure herbaceous layer biomass, we studied $10-25$ subplots $(0.5 \times 0.5 \mathrm{~m})$ within each sampling area over period of maximum grass stand (July). All collected samples were then assorted by species, dried till absolutely dry, and weighed.

All the studied forests were grouped by their succession status into several succession series. In a series, sampling plots were grouped according to tree stand age. Such an approach to the study of successions in forests (singling out a range of succession series) is becoming more popular, and usually brings good results (Ivanova, Zolotova, 2014). We singled out and studied the following successional series (Table 1): natural spruce forests (140 and 160 age), after-cutting (secondary) spruce and fir forests (50, 65 and 70 age), short-term secondary birch forests $(5,20$, 
80 and 100 age), long-term secondary birch forests (20,35, 50 and 100 age) and stable-term aspen forests $(8,20$, 65 and 110 age).

Natural spruce forests included 140-160-year-old dark coniferous forests that had suffered little cuttings or fires. These forests had retained their original stand and subordinate layers structure. Short-term secondary birch forests included after-cutting forests with prevailing Betula pubescens, occurring Picea obovata and Abies sibirica in stand, and plentiful viable understory of dark conifers below the canopy. Picea obovata and Abies sibirica were virtually absent in the stand and under the canopy of the long-term secondary birch forests. Stable-term aspen forests included forests with aspen prevailing in their stand and no viable dark conifers in understory.

\subsection{Data Analysis}

We used the biomass data to perform the Correspondence Analysis (CA). Correspondence analysis (CA) is a multivariate statistical technique developed by Jean-Paul Benzécri (1973). This method is described in detail by Michael J. Greenacre (1984). Recently, the CA has become very popular for the study of forests (Ter Braak, 1987; Oliver et al, 2000; Wulder et al., 2009; Lippok et al., 2014). The method is implemented in a number of application software packages: CANOCO (Gilliam et al., 2003), DECORANA (Hill, Gauch, 1980). It is conceptually similar to principal component analysis, but applies to categorical rather than continuous data. In a similar manner to principal component analysis, it provides a means of displaying or summarising a set of data in two-dimensional graphical form. The purpose of correspondence analysis is to reproduce the distances between the row and/or column points in a two-way table in a lower-dimensional display. In the study of forests the ordination diagram generated by CA visualizes a pattern of vegetation variation. The ultimate goal of correspondence analysis is to find a theoretical interpretation of the obtained results. One method that may aid in interpreting of extracted dimensions is an analysis of the factors. We were interested in how the external factor (clear-cuttings) initiates regeneration processes and what factors determine the direction of the dynamics of forest vegetation. For the numerical analysis of community data, R package vegan (version 2.15.1 (2012-06-22)) (Oksanen, 2013) was used.

Table 1. Tree stand characteristics of the studied mountain dark conifers and short-secondary birch forests in Southern Urals

\begin{tabular}{|c|c|c|c|c|c|c|c|c|c|}
\hline \multirow{2}{*}{$\begin{array}{l}\text { Successional status } \\
\text { Plot No. }\end{array}$} & \multicolumn{2}{|c|}{$\begin{array}{l}\text { Natural dark } \\
\text { coniferous forests }\end{array}$} & \multicolumn{3}{|c|}{$\begin{array}{l}\text { After-cutting spruce and fir } \\
\text { forests }\end{array}$} & \multicolumn{2}{|c|}{$\begin{array}{l}\text { Short-term } \\
\text { forests }\end{array}$} & econdary & \multirow{2}{*}{$\begin{array}{r}\text { birch } \\
38-41\end{array}$} \\
\hline & $1-4$ & $5-8$ & $9-12$ & $13-17$ & $18-25$ & $26-29$ & $30-33$ & $34-37$ & \\
\hline Age, years & 160 & 140 & 50 & 65 & 70 & 5 & 20 & 80 & 100 \\
\hline Stand density, $\mathrm{m}^{2} \mathrm{ha}^{-1}$ & 32.7 & 23.4 & 19.3 & 28.4 & 20.8 & - & 16.1 & 28.2 & 35.7 \\
\hline $\begin{array}{l}\text { Percentage in the stand } \\
\text { composition: } \\
\text { Picea obovata Ledeb. }\end{array}$ & 80 & 30 & 50 & 30 & 40 & - & + & 30 & 50 \\
\hline Abies sibirica Ledeb. & 10 & 50 & 50 & 30 & + & - & 30 & 20 & 10 \\
\hline Pinus sylvestris L. & - & - & + & 20 & 30 & - & 10 & 10 & - \\
\hline Betula pubescens Ehrh. & + & 20 & + & 20 & 30 & - & 60 & 40 & 40 \\
\hline
\end{tabular}

Note. + Species occurs sporadically.

Table 2. Tree stand characteristics of the studied long-term secondary birch and stable-term secondary aspen in Southern Urals

\begin{tabular}{lcccccccc}
\hline Successional status & \multicolumn{1}{c}{ Long-term secondary birch forests } & \multicolumn{2}{c}{ Stable-term secondary aspen forests } \\
\hline Plot No. & $42-45$ & $46-49$ & $50-53$ & $56-57$ & $58-61$ & $62-65$ & $66-69$ & $70-72$ \\
Age, years & 20 & 35 & 50 & 100 & 8 & 20 & 65 & 110 \\
Stand density, $\mathrm{m}^{2} \mathrm{ha}^{-1}$ & 5.4 & 18.5 & 29.5 & 20.7 & - & - & 28.3 & 28.4 \\
Percentage in the stand composition: & & & & & & & & \\
Picea obovata Ledeb. & 10 & 10 & 10 & 10 & - & + & - & + \\
Abies sibirica Ledeb. & + & + & - & - & - & 10 & 10 & + \\
Pinus sylvestris L. & - & - & + & 20 & - & - & - & - \\
Betula pubescens Ehrh. & 90 & 90 & 90 & 70 & - & 10 & 10 & 10 \\
Populus tremula L. & - & - & - & + & - & 80 & 80 & 90 \\
\hline
\end{tabular}




\section{Results and Discussion}

The Southern Ural mountain forests studied by us had a gross productivity of the grass and low shrub ranging from 24.6 to $233.0 \mathrm{gm}^{-2}$ in the absolutely dry state. Gross biomass of grasses and low shrubs under the canopy of natural spruce forests amounted to $32.6-37.8 \mathrm{gm}^{-2}$ in the absolutely dry state. After clear-cuttings, herbaceous productivity increased in all the studied ecological series: up to $53.6-77.9 \mathrm{gm}^{-2}$ in secondary dark coniferous forests, up to 41.9-99.1 $\mathrm{gm}^{-2}$ in short-term secondary birch forests, up to $57.7-100.1 \mathrm{gm}^{-2}$ in long-term secondary birch forests, and up to $96.8-233.0 \mathrm{gm}^{-2}$ in stable-term secondary aspen forests. Short-term and long-term secondary birch forests tended to regain productivity of the lower layers (faster in short-term secondary forests, and slower in long-term secondary forests). This tendency however was not found in stable-term secondary aspen forests.

Table 3. The most abundant species of the studied forests grass layer

\begin{tabular}{|c|c|c|c|c|c|}
\hline Plot & Rank: 1 & Rank: 2 & Rank: 3 & Rank: 4 & Rank: 5 \\
\hline $1-4$ & $\begin{array}{l}\text { Lycopodium clavatum } \\
\text { L. }\end{array}$ & $\begin{array}{l}\text { Calamagrostis } \\
\text { arundinacea }(\mathrm{L} .) \\
\text { Roth }\end{array}$ & Ajuga reptans L. & $\begin{array}{l}\text { Dryopteris expansa }(\mathrm{C} . \\
\text { Presl) Fraser-Jenkins \& } \\
\text { Jermy }\end{array}$ & $\begin{array}{l}\text { Equisetum } \\
\text { sylvaticum } \mathrm{L} .\end{array}$ \\
\hline $5-8$ & Equisetum sylvaticum L. & $\begin{array}{l}\text { Athyrium } \\
\text { filix-femina (L.) Roth }\end{array}$ & $\begin{array}{l}\text { Calamagrostis } \\
\text { arundinacea (L.) Roth }\end{array}$ & Lycopodium annotinum L. & $\begin{array}{l}\text { Lycopodium } \\
\text { clavatum } \mathrm{L} \text {. }\end{array}$ \\
\hline $9-12$ & Ajuga reptans $\mathrm{L}$. & $\begin{array}{l}\text { Calamagrostis } \\
\text { arundinacea }(\mathrm{L} .) \\
\text { Roth }\end{array}$ & Carex pilosa Scop. & $\begin{array}{l}\text { Deschampsia cespitosa (L.) } \\
\text { Beauv. }\end{array}$ & Rubus saxatilis $\mathrm{L}$. \\
\hline $13-17$ & $\begin{array}{l}\text { Calamagrostis } \\
\text { arundinacea }(\mathrm{L} .) \text { Roth }\end{array}$ & Carex pilosa Scop. & Vaccinium myrtillus L. & Veratrum lobelianum Bernh. & $\begin{array}{l}\text { Succisa pratensis } \\
\text { Moench }\end{array}$ \\
\hline $18-25$ & $\begin{array}{l}\text { Filipendula ulmaria }(\mathrm{L} .) \\
\text { Maxim. }\end{array}$ & Carex pilosa Scop. & $\begin{array}{l}\text { Aconitum } \\
\text { septentrionale Koelle }\end{array}$ & $\begin{array}{l}\text { Carex rhizina Blytt ex } \\
\text { Lindbl. }\end{array}$ & $\begin{array}{l}\text { Calamagrostis } \\
\text { arundinacea }(\mathrm{L} .) \\
\text { Roth }\end{array}$ \\
\hline $26-29$ & $\begin{array}{l}\text { Calamagrostis } \\
\text { arundinacea }(\mathrm{L} .) \text { Roth }\end{array}$ & $\begin{array}{l}\text { Phalaroides } \\
\text { arundinacea (L.) } \\
\text { Rauschert }\end{array}$ & $\begin{array}{l}\text { Calamagrostis } \\
\text { epigeios (L.) Roth }\end{array}$ & Carex pallescens L. & $\begin{array}{l}\text { Bistorta major S.F. } \\
\text { Gray }\end{array}$ \\
\hline $30-33$ & Carex pilosa Scop. & Rubus saxatilis $\mathrm{L}$. & $\begin{array}{l}\text { Brachypodium } \\
\text { pinnatum }(\mathrm{L} .) \text { Beauv. }\end{array}$ & Geranium sylvaticum L. & $\begin{array}{l}\text { Calamagrostis } \\
\text { arundinacea }(\mathrm{L} .) \\
\text { Roth }\end{array}$ \\
\hline $34-37$ & $\begin{array}{l}\text { Dryopteris filix-mas } \\
\text { (L.) Schott }\end{array}$ & $\begin{array}{l}\text { Brachypodium } \\
\text { pinnatum }(\mathrm{L} .) \text { Beauv. }\end{array}$ & Ajuga reptans L. & Prunella vulgaris L. & $\begin{array}{l}\text { Asarum europaeum } \\
\text { L. }\end{array}$ \\
\hline $38-41$ & $\begin{array}{l}\text { Stellaria bungeana } \\
\text { Fenzl }\end{array}$ & $\begin{array}{l}\text { Calamagrostis } \\
\text { arundinacea }(\mathrm{L} .) \\
\text { Roth }\end{array}$ & $\begin{array}{l}\text { Aconitum } \\
\text { septentrionale Koelle }\end{array}$ & Milium effusum $\mathrm{L}$. & Circaea alpina $\mathrm{L}$. \\
\hline $42-45$ & $\begin{array}{l}\text { Brachypodium } \\
\text { pinnatum (L.) Beauv. }\end{array}$ & Carex pilosa Scop. & $\begin{array}{l}\text { Calamagrostis } \\
\text { arundinacea }(\text { L.) Roth }\end{array}$ & Festuca gigantea (L.) Vill. & $\begin{array}{l}\text { Aegopodium } \\
\text { podagraria } \mathrm{L} \text {. }\end{array}$ \\
\hline $46-49$ & Carex pilosa Scop. & $\begin{array}{l}\text { Calamagrostis } \\
\text { arundinacea }(\mathrm{L} .) \\
\text { Roth }\end{array}$ & $\begin{array}{l}\text { Brachypodium } \\
\text { pinnatum (L.) Beauv. }\end{array}$ & $\begin{array}{l}\text { Stachys officinalis (L.) } \\
\text { Trevis. }\end{array}$ & $\begin{array}{l}\text { Aegopodium } \\
\text { podagraria } \mathrm{L} .\end{array}$ \\
\hline $50-53$ & $\begin{array}{l}\text { Brachypodium } \\
\text { pinnatum (L.) Beauv. }\end{array}$ & Carex pilosa Scop. & $\begin{array}{l}\text { Aconitum } \\
\text { septentrionale Koelle }\end{array}$ & Aegopodium podagraria $\mathrm{L}$. & $\begin{array}{l}\text { Calamagrostis } \\
\text { arundinacea }(\mathrm{L} .) \\
\text { Roth }\end{array}$ \\
\hline $56-57$ & Carex pilosa Scop. & Carex pallescens $\mathrm{L}$. & $\begin{array}{l}\text { Aconitum } \\
\text { septentrionale Koelle }\end{array}$ & $\begin{array}{l}\text { Calamagrostis arundinacea } \\
\text { (L.) Roth }\end{array}$ & Stellaria holostea L. \\
\hline $58-61$ & $\begin{array}{l}\text { Calamagrostis } \\
\text { arundinacea }(\mathrm{L} .) \text { Roth }\end{array}$ & Geum rivale L. & $\begin{array}{l}\text { Calamagrostis } \\
\text { epigeios (L.) Roth }\end{array}$ & $\begin{array}{l}\text { Filipendula ulmaria }(\mathrm{L} .) \\
\text { Maxim. }\end{array}$ & $\begin{array}{l}\text { Bistorta major S.F. } \\
\text { Gray }\end{array}$ \\
\hline $62-65$ & $\begin{array}{l}\text { Calamagrostis } \\
\text { arundinacea }(\mathrm{L} .) \text { Roth }\end{array}$ & $\begin{array}{l}\text { Brachypodium } \\
\text { pinnatum }(\mathrm{L} .) \text { Beauv. }\end{array}$ & $\begin{array}{l}\text { Aconitum } \\
\text { septentrionale Koelle }\end{array}$ & Carex pilosa Scop. & $\begin{array}{l}\text { Pulmonaria } \\
\text { obscura Dumort. }\end{array}$ \\
\hline $66-69$ & $\begin{array}{l}\text { Aconitum } \\
\text { septentrionale Koelle }\end{array}$ & Stachys sylvatica L. & $\begin{array}{l}\text { Dryopteris filix-mas } \\
\text { (L.) Schott }\end{array}$ & Stellaria bungeana Fenzl & $\begin{array}{l}\text { Crepis paludosa } \\
\text { (L.) Moench }\end{array}$ \\
\hline $70-72$ & $\begin{array}{l}\text { Aconitum } \\
\text { septentrionale Koelle }\end{array}$ & Stachys sylvatica L. & $\begin{array}{l}\text { Calamagrostis } \\
\text { arundinacea }(\mathrm{L} .) \text { Roth }\end{array}$ & Geum rivale L. & $\begin{array}{l}\text { Calamagrostis } \\
\text { epigeios (L.) Roth }\end{array}$ \\
\hline
\end{tabular}

Tables 3 and 4 clearly demonstrate that the variety of the most plentiful species does not remain permanent in the course of regeneration age successions of the tree stands. Under the canopy of natural spruce forests, prevalent are 
Lycopodium annotinum, L. clavatum, Equisetum sylvaticum, Dryopteris expansa, Dryopteris carthusiana, Athyrium filix-femina, Phegopteris connectilis, Ajuga reptans, Calamagrostis arundinacea. In secondary forests such species as Calamagrostis arundinacea, Brachypodium pinnatum, and Carex pilosa prevail in most cases.

The most interesting productivity dynamics was exposed by Calamagrostis arundinacea (Table 3 and 4). This species is a dominant in the grass and low shrub layer both in natural spruce forests and most secondary forests. In after-cutting dark conifers, its biomass is typically much higher (by a factor of 3 or 4). In short-term birch forests, it is at a maximum at the early stages of the tree stand regeneration age successions, and at a minimum towards the middle stages. On the contrary, in long-term secondary birch forests the biomass of Calamagrostis arundinacea is at a maximum near the middle of regeneration-age successions, and at a minimum towards the end. In stable-term secondary aspen forests Calamagrostis arundinacea's biomass remains sufficiently high throughout the whole cycle.

Brachypodium pinnatum and Carex pilosa prevail at the middle stages of the regeneration-age successions in short-term, long-term, and stable-term secondary aspen forests. In after-cutting dark coniferous forests their productivity is also significantly higher compared to subnatural spruce forests. In stable-term secondary aspen forests, the most plentiful are Aconitum excelsum, Stachys sylvatica, Dryopteris filix-mas, Calamagrostis arundinacea, Geum rivale, and Stellaria bungeana.

Table 4. Productivity of the most abundant species of the grass layer

\begin{tabular}{lrrrrrrrrrr}
\hline Plot No. & \multicolumn{1}{c}{ Rank: 1} & \multicolumn{3}{c}{ Rank: 2} & \multicolumn{2}{c}{ Rank: 3} & \multicolumn{2}{c}{ Rank: 4} & \multicolumn{3}{c}{ Rank: 5} \\
\hline & $\mathrm{M}_{\text {, gm }}^{-2}$ & $\mathrm{Kv}$ & $\mathrm{M}^{-2} \mathrm{gm}^{-2}$ & $\mathrm{Kv}$ & $\mathrm{M}, \mathrm{gm}^{-2}$ & $\mathrm{Kv}$ & $\mathrm{M}, \mathrm{gm}^{-2}$ & $\mathrm{Kv}$ & $\mathrm{M}, \mathrm{gm}^{-2}$ & $\mathrm{Kv}$ \\
$5-4$ & 13.62 & 123 & 5.98 & 206 & 2.38 & 164 & 2.22 & 224 & 2.10 & 218 \\
$9-12$ & 12.54 & 169 & 6.9 & 346 & 5.51 & 177 & 4.33 & 225 & 4.11 & 204 \\
$13-17$ & 3.32 & 121 & 2.77 & 131 & 2.67 & 98 & 2.6 & 214 & 2.17 & 166 \\
$18-25$ & 20.75 & 152 & 11.47 & 141 & 5.14 & 204 & 2.59 & 348 & 2.45 & 224 \\
$26-29$ & 32.64 & 10 & 17.45 & 140 & 5.11 & 140 & 3.86 & 205 & 1.22 & 117 \\
$30-33$ & 35.30 & 80 & 17.62 & 205 & 11.54 & 357 & 6.50 & 288 & 4.34 & 183 \\
$34-37$ & 13.90 & 87 & 5.12 & 144 & 5.06 & 94 & 3.5 & 229 & 2.2 & 177 \\
$38-41$ & 3.44 & 310 & 2.42 & 369 & 2.36 & 110 & 2.34 & 122 & 2.34 & 203 \\
$42-45$ & 8.58 & 165 & 6.68 & 199 & 3.71 & 277 & 2.44 & 295 & 2.44 & 228 \\
$46-49$ & 35.47 & 76 & 8.77 & 93 & 8.22 & 167 & 5.17 & 168 & 4.86 & 68 \\
$50-53$ & 35.85 & 49 & 17.63 & 92 & 4.47 & 173 & 2.93 & 185 & 2.51 & 112 \\
$56-57$ & 7.55 & 120 & 6.29 & 100 & 3.50 & 22 & 2.11 & 138 & 2.01 & 224 \\
$58-61$ & 21.38 & 125 & 12.76 & 180 & 8.30 & 224 & 2.99 & 165 & 2.16 & 36 \\
$62-65$ & 17.79 & 106 & 16.28 & 92 & 14.47 & 165 & 13.01 & 76 & 11.63 & 112 \\
$66-69$ & 18.20 & 84 & 9.92 & 113 & 6.90 & 248 & 4.86 & 175 & 3.84 & 146 \\
$70-72$ & 32.99 & 99 & 30.18 & 176 & 10.68 & 400 & 10.59 & 63 & 9.56 & 132 \\
\hline
\end{tabular}

Note. $\mathrm{M}$ - aboveground biomass in a completely dry state, $\mathrm{Kv}-$ coefficient of variation

The Tables (1-4) describes the structure of the studied forests and cuttings. The differentiation of forest vegetation is visible more clearly on the ordination diagram. We used data on the biomass of grass to build the ordination diagram. These data are partially shown in Tables 3 and 4. Figure 1 shows the divergence of forest vegetation after clear-cutting in the Southern Ural Mountains in the CA axes and estimates the distance between the studied objects (forests and cutting) in the multidimensional feature space (species composition). The first two axes explain 19.9 and $13.6 \%$ of the total variance. Correspondence analysis (CA) revealed that after-cutting forests differ from natural spruce forests in the structure of their herbaceous biomass and that these differences remain for a long time. After-cutting spruce and fir forests are closest to the natural type forests. Nevertheless, natural and after-cutting dark conifers are clearly separated in the CA axes. Also, we observe a change of the dominant species (Table 3). Short-term and long-term secondary birch forests are more remote from the natural forests (Figure 1). These forests are more differences from natural forests on the species composition (Table 3). No differences are found between short-term and long-term secondary birch forests and their regeneration-age stages. This testifies to their structure stability. A distinctive feature of these forests is the abundance of Brachypodium pinnatum and Carex pilosa (Table 3). Stable-term secondary aspen forests and clear-cuttings are the farthest from natural forests (Figure 1). A list of the most abundant species is changing almost completely (Table 3). Different age stages of the stable-term secondary aspen forests take different positions in the CA axes (Figure 1). This testifies to major 
alterations in their structure. We are seeing a strengthening of the role of Aconitum septentrionale and Stachys sylvatica with increasing stand age (Table 3). Cuttings overgrown with birch and aspen form isolated groups in the CA axes. These groups lie apart from of all the other forest ecosystems we have studied. Objects layout in the CA axes allows us to conclude that.

The first CA axis separates green-moss small-grass forests (spruce and fir) from tall-grass forests (aspen). Short-term and long-term secondary birch forests are positioned in between.

The second CA axis discriminates between the forests and clear-cuttings.

Thus, the first CA axis characterizes inner regeneration-age processes in an ecosystem, while the other CA axis is associated with the external catastrophic factor (cuttings) destroying the community structure. As a result, Figure 1 clearly shows how the external destructive factor (clear-cuttings) initiates regeneration processes. There are different kinds of clear-cuttings. They are carried out in different seasons (summer-winter) preserving the understory Picea obovata and Abies sibirica, or destroying it in the course of lumbering. These aspects are reflected in regeneration successions.

To test the hypothesis of close interconnection of regeneration-age successions with forest ecosystem edificators, we analyzed the correlation between the structure and dynamics of tree and herbaceous layers. For this purpose we introduced to Figure 1 vectors characterizing the tree layer. We used the data shown in Tables 1 and 2 . Table 5 shows that the herbaceous layer structure within the sampling plots was mainly determined by Picea obovata, Abies sibirica and Populus tremula. Tree stand age was another significant factor. Pinus sylvestris abundance in the Southern Ural Mountains is associated with fires which often accompany cuttings. However in the studied forests, even those suffering from repeated brush-wood fires, this tree species was not an edificator. Its influence on the grass layer productivity was not crucial.

Table 5. Tree stand vectors

\begin{tabular}{llllc}
\hline & CA1 & CA2 & $\mathrm{r}^{2}$ & $\operatorname{Pr}(>\mathrm{r})$ \\
\hline Picea obovata Ledeb. and & -0.996 & -0.091 & 0.67 & 0.001 \\
Abies sibirica Ledeb. (percentage in the stand composition) & & & & \\
Betula pubescens Ehrh. (percentage in the stand composition) & -0.617 & -0.787 & 0.15 & 0.022 \\
Pinus sylvestris L. (percentage in the stand composition) & -0.966 & 0.259 & 0.04 & 0.359 \\
Populus tremula L. (percentage in the stand composition) & 0.863 & -0.506 & 0.67 & 0.001 \\
Age, years & -0.752 & -0.659 & 0.21 & 0.005 \\
\hline
\end{tabular}

Clear-cuttings are common in the Southern Ural Mountains. After-cutting changes in the vegetation structure found in the study are typical in large areas. Forest fund structure analysis conducted by G.V. Andreev shows that dark conifers now remain only on $16 \%$ of areas with the studied conditions (Ivanova, Andreev, 2008a). These are mainly after-cutting and after-fire spruce and fir forests at various stages of regeneration. They emerge from pre-regeneration understory surviving after lumbering or after natural disruption of birch and aspen forests (rarely on fire sites). Natural dark conifers have survived within an insignificant area. Short-term secondary birch forests occupy only 4\% of the total area (Ivanova, Andreev, 2008b), long-term secondary birch forests - 62\% (Ivanova, Andreev, 2008c), stable-term secondary aspen forests $-25 \%$ of the area; they have little or no spruce or fir (Ivanova, Andreev, 2008d). The data allows us to conclude that the forest ecosystems within the most common type of forest are enormously mosaic. This is mainly caused by clear-cuttings that lead to dramatic decrease of Picea obovata and Abies sibirica in the forest structure.

Our study allows us to identify new research objectives:

- $\quad$ To develop theoretical and methodical base for analyzing and predicting forest vegetation dynamics with regard to its great divergence and polyvariant development.

- $\quad$ To develop effective quantitative methods of identifying emergency situations in forest ecosystems.

- $\quad$ To classify forest ecosystems with regard to their dynamics.

These issues will be subject of our further studies.

\section{Conclusion}

To summarize, clear-cuttings in the Southern Ural Mountains cause profound transformation of forest vegetation structure in all layers. Patterns of regeneration-age dynamics differ both in tree stand and herbaceous layer: within 
a single natural forest, a whole range of alternative successional series are formed - spruce, fir, birch, and aspen forests (short-term, long-term, and stable-term secondary), each having specific grass productivity. All the studied after-cutting forests (after-cutting (secondary) 50-70-year-old spruce and fir forests, short-term secondary birch forests (age of 5-100), long-term secondary birch forests (age of 20-100), and 8-110-year-old stable-term secondary aspen forests) differ from natural dark coniferous forests in the structure of grass biomass and dynamic patterns.

Nature protection and forestry measures in the Southern Urals must take into account the described specifics of the forest vegetation divergence after clear-cuttings in order to preserve the unique mountain dark coniferous forests.

Most of the forests of our planet are subject to anthropogenic influences. Processes of forest transformation occur everywhere. Our study develops a new direction in forest science: the study of the features of differentiation of forest vegetation within one ecotope. The solution to this problem is useful for understanding the evolution of modern ecosystems in terms of human impact and climate change.

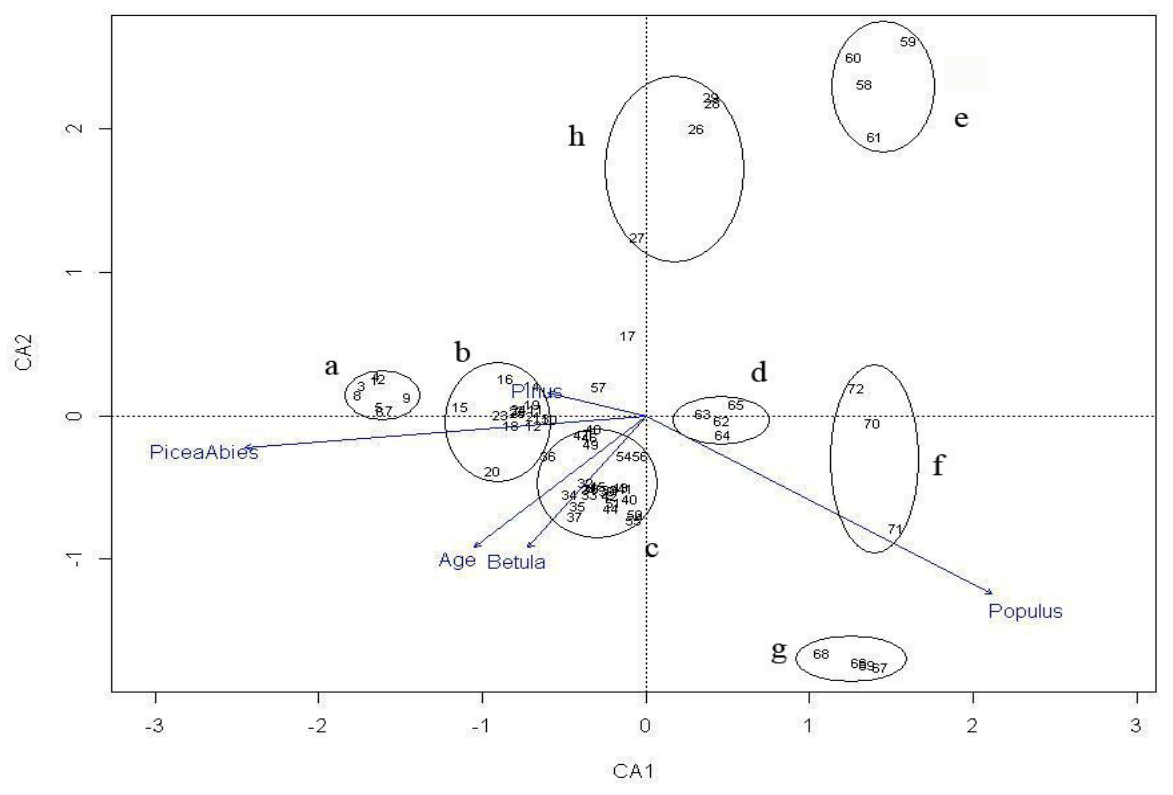

Figure 1. Differentiation of forest vegetation (in CA axes) after clear-cuttings in the ecotope (lower parts of smooth drained slopes with deep brown mountain forest soils) in the Southern Ural Mountains

Note. a - natural spruce forests, $\mathrm{b}$ - after-cutting spruce and fir forests, $\mathrm{c}$ - short-term and long-term secondary birch forests, $\mathrm{d}$ - stable-term secondary 20-year-old aspen forests, e - cuttings with aspen growth (Populus tremula L.), $\mathrm{f}$ - old-aged aspen forests, g - 65-year old aspen forests, $\mathrm{h}$ - clear-cuttings with birch growth (Betula pubescens Ehrh.), Picea, Abies, Betula, Populus, Pinus - percentage in the species composition Picea obovata Ledeb., Abies sibirica Ledeb., Betula pubescens Ehrh., Populus tremula L., Pinus sylvestris L. respectively, Age stand age (years).

\section{Acknowledgments}

This work was supported supported by the program of the Presidium of RAS 12-P-4-1060. PhD in Agriculture Georgy V. Andreev has lent us great assistance in our research and provided forest characteristics of the studied forests tree stand. We greatly appreciate that.

\section{References}

Andreev, G. V. (1998). Analysis of the Typological Structure of the Forest Lands within the Southern Ural Province of South Taiga and Mixed Forests. Contemporary Issues of the Population, Historical and Applied Ecology. Conference Materials. Yekaterinburg: Ekaterinburg Publishing House. pp. 231-232.

Asner, G. P., Rudel, T. K., Aide, T. M., Defries, R., \& Emerson, R. (2009). A contemporary assessment of change in humid tropical forests. Conserv Biol, 23, 1386-1395. http://dx.doi.org/10.1111/j.1523-1739.2009.01333.x 
Benzécri, J. P. (1973). L'Analyse des Données. Volume II. L'Analyse des Correspondances. Paris, France: Dunod.

Forest Communities Study Methods. (2002). St. Petersburg: Chemistry R\&D Institute of St. Petersburg State University. p240 .

Forster, D. R. (1988). Disturbance history, community organization and vegetation dynamics of the old-growth Pisgah Forest, south-western New Hampshire, U.S.A. J. Ecol., 76(1), 105-134. http://dx.doi.org/10.2307/2260457

Gilliam, F. S., \& Saunders, N. E. (2003). Making more sense of the order: A review of Canoco for Windows 4.5, PC-ORD version 4. Journal of Vegetation Science, 14(2), 297-304. http://dx.doi.org/10.1111/j.1654-1103.2003.tb02155.x

Global Biodiversity Outlook. (2006). 2. - Montreal: Secretariat of the Convention on Biological Diversity. Retrieved from https://www.cbd.int/doc/gbo/gbo2/cbd-gbo2-en.pdf

Greenacre, M. J. (1984). Theory and Applications of Correspondence Analysis. Academic Pr. P. 364 .

Hill, M. O., \& Gauch, H. G. (1980). Detrended correspondence analysis: An improved ordination technique. Vegetatio, 42(1-3), 47-58. http://dx.doi.org/10.1007/BF00048870

Ivanova, N. S. (2014). Recovery of Tree Stand after Clear-Cutting in the Ural Mountains. International Journal of Bio-Resource and Stress Management, 5(1), 090-092. http://dx.doi.org/10.5958/j.0976-4038.5.1.017

Ivanova, N. S., \& Zolotova, E. S. (2014). Development of Forest Typology in Russia. International Journal of Bio-Resource and Stress Management, 5(2), 298-303. http://dx.doi.org/10.5958/0976-4038.2014.00572.7

Ivanova, N., \& Andreev, G. (2008a). The Natural Regeneration of Picea obovata Ledeb.and Abies sibirica Ledeb. Cenopopulations in Dark-coniferous Forests of Southern Urals. Agrarian bulletin of Ural (Agrarnyj vestnik Urala), 6, 82-86. Retrieved from http://elibrary.ru/item.asp?id=11018258

Ivanova, N., \& Andreev, G. (2008b). The Natural Regeneration of Picea obovata Ledeb.and Abies sibirica Ledeb. Cenopopulations in Short-term Secondary Birch Forests of Southern Urals Mountains. Agrarian Bulletin of Ural (Agrarny Vestnik Urala), 7, 75-77. Retrieved from http://elibrary.ru/item.asp?id=11528998

Ivanova, N., \& Andreev, G. (2008c). The Natural Regeneration of Picea obovata Ledeb.and Abies sibirica Ledeb. Cenopopulations in Long-term Secondary Birch Forests of Southern Urals Mountains. Agrarian bulletin of Ural (Agrarnyj vestnik Urala), 8, 74-76. Retrieved from http://elibrary.ru/item.asp?id=11544006

Ivanova, N., \& Andreev, G. (2008d). The Permanent Secondary Aspen Forests of the Western Low Mountains of the Southern Urals. Agrarian Bulletin of Ural (Agrarny Vestnik Urala), 10, 91-93. Retrieved from http://elibrary.ru/item.asp?id=11723233

Kolesnikov, B. P. (1969). The Chelyabinsk Region Forests, 4, 125-156. USSR Forests. Moscow: Science.

Lindenmayer, D., Burns, E., Thurgate, N., \& Lowe, A. (2014). Biodiversity and Environmental Change: Monitoring, Challenges and Direction. CSIRO PUBLISHING, p624.

Lippok, D., Beck, S. G., Renison, D., Hensen, I., Apaza, A. E., \& Schleuning, M. (2014). Topography and edge effects are more important than elevation as drivers of vegetation patterns in a neotropical montane forest. Journal of Vegetation Science, 25(3), 724-733. http://dx.doi.org/10.1111/jvs.12132

Oksanen, J. (2013). Multivariate Analysis of Ecological Communities in R: Vegan Tutorial. Retrieved from http://vegan.r-forge.r-project.org/

Oliver, I., Mac Nally, R., \& York, A. (2000). Identifying performance indicators of the effects of forest management on ground-active arthropod biodiversity using hierarchical partitioning and partial canonical correspondence analysis. Forest Ecology and Management, 139(1-3), 21-40. http://dx.doi.org/10.1016/S0378-1127(99)00343-6

Shirokikh, P. S., Martynenko, V. B., \& Kunafin, A. M. (2013). Experience in Syntaxonomic and Ordination Analysis of Progressive Succession in Cutover Areas of Boreal Light Conifer Forests in the Southern Urals. Russian Journal of Ecology, 44(3), 185-192. http://dx.doi.org/10.1134/S1067413613030120

Ter Braak, C. J. F. (1987). The analysis of vegetation-environment relationships by canonical correspondence analysis. Vegetatio, 69(1-3), 69-77. http://dx.doi.org/10.1007/BF00038688

van Breugel, M., Hall, J. S., Craven, D., Bailon, M., \& Hernandez, A., et al. (2013). Succession of Ephemeral Secondary Forests and Their Limited Role for the Conservation of Floristic Diversity in a Human-Modified Tropical Landscape. PLoS ONE, 8(12), e82433. http://dx.doi.org/10.1371/journal.pone.0082433. 
Wulder, M. A., Whitea, J. C. Andrewa, M. E. Seitza, N. E., \& Coopsb, N. C. (2009). Forest fragmentation, structure, and age characteristics as a legacy of forest management. Forest Ecology and Management, 258(9), 1938-1949. http://dx.doi.org/10.1016/j.foreco.2009.07.041

\section{Copyrights}

Copyright for this article is retained by the author(s), with first publication rights granted to the journal.

This is an open-access article distributed under the terms and conditions of the Creative Commons Attribution license (http://creativecommons.org/licenses/by/3.0/). 